\title{
Ifistory of $\mathbb{Z}_{2} \mathfrak{z r t h}$ Carolina Jzibraries and İibrarianship. A Bibliography

\author{
Part I
}

— Compiled by Wiley J. Williams

\begin{abstract}
$\mathfrak{I}$ ollowing a suggestion by Robert G. Anthony, Jr., Curator of the North Carolina Collection at the University of North Carolina at Chapel Hill, I set about compiling this work, which is modeled on and incorporates materials gathered for earlier bibliographies published by Ray Carpenter, Bea Bruce, and Michele Oliver in 1971 and by Robert G. Anthony, Jr. in $1992 .^{1}$

This bibliography, like Donald G. Davis, Jr. and John Mark Tucker's American Library History: A Comprehensive Guide to the Literature (1989) and its predecessor, American Library History: A Bibliography (1978) by Michael H. Harris and Donald G. Davis, Jr., should be considered comprehensive and not exhaustive, as it too omits clipping file items, annual reports, newsletters, and handbooks that many libraries have published. Unlike Carpenter's bibliography, this one selectively includes master's papers, especially those from the University of North Carolina at Chapel Hill and North Carolina Central University.

In addition to the Davis and Tucker guide, Journal of Library History, Libraries \& Culture, and the ALA Library History Roundtable Newsletter (1978- ) have proved indispensable. Useful items were turned up in such standard library and information science periodicals as American Archivist, American Libraries, College \& Research Libraries, Journal of Education for Library and Information Science, Library Literature, Library Quarterly, North Carolina Libraries, and Southeastern Librarian. Each issue of North Carolina Historical Review (1934-2003) was examined for "North Carolina Bibliography" and each January issue of the same journal (1979-2003) was consulted for "Selected Bibliography of Completed Theses and Dissertations Related to North Carolina Subjects."

The bibliography will be published in four parts, one in each of the next four issues of North Carolina Libraries. The first installment in includes general historical works about North Carolina public libraries, and histories of libraries from (alphabetically) Alamance through Guilford counties. Part two of the bibliography will contain histories of public libraries from Halifax through Yadkin Counties, part three will include references to general works on North Carolina library history and histories of special libraries in the state, and part four will describe materials on college and university libraries, school libraries, and library associations. Many of the works about individual libraries may not be considered traditional library history, however, an effort has been made to include all works that may be of use to librarians and researchers who are studying specific institutions.

\section{Reference}

${ }^{1}$ See Ray Carpenter, Bea Bruce, and Michele Oliver, "A Bibliography of North Carolina Library History," Journal of Library History 6 (July 1971): 212-264; and Robert G. Anthony Jr., "History of Tar Heel Libraries and Librarianship as Found in North Carolina Libraries and North Carolina Library Bulletin: A Bibliography," North Carolina Libraries 50 (Spring 1992): 42-47.
\end{abstract}




\section{Public Libraries}

Anders, Mary Edna. "The Development of Public Library Service in the Southeastern States, 1895-1940." D.L.S. Dissertation, Columbia University, 1958. 290 pp.

The Tennessee Valley Library Council, 1940-1949: A Regional Approach to Library Planning. Atlanta: Southeastern Library Association, 1960. 48 pp.

Atkins, Eliza. "The Government and Administration of Public Library Service to Negroes in the South." Ph.D. Dissertation, University of Chicago, 1940. 173 pp.

Bell, Bernice Lloyd. "Integration in Public Library Service in Thirteen Southern States, 1954-1963." Master's Thesis, Atlanta University, 1963. 134 pp.

"Public Library Integration in Thirteen Southern States [1954-1963]." Library Journal 88 (Dec. 15, 1963): 4713-15.

Bobinski, George S. "Carnegie Libraries: Their History and Impact on American Public Library Development." Bulletin of the American Library Association 62 (Dec. 1968): 1361-67.

Boone, Angela L. "Readers' Advisory Service in the Public Library: Past, Present, and Future." Master's Paper, School of Information and Library Science, University of North Carolina at Chapel Hill, 1996. 32 pp.

Brandel, Emily. "A History of Adult Education in the Public Library from 1900 to the Present." Master's Paper, School of Information and Library Science, University of North Carolina at Chapel Hill, 1997. 22 pp.

Buchanan, William Emory. "The Yazoo Library Association's Significance in History: The American Social and Public Library Movements in the South." Ed.D. Dissertation, University of North Carolina at Greensboro, 1992. 207 pp.

Craig, Calvin Hamrick. "An Examination of Collectors of Local History Materials in Four North Carolina Public Libraries." Master's Paper, School of Information and Library Science, University of North Carolina at Chapel Hill, 1999. 64 pp.

Ewing, Leah G. "Top Administrators of North Carolina Public Libraries, Fiscal Years 1975/1976 - 1995/1996: An Examination in Terms of Sex and Size of Population Served." Master's Paper, School of Information and Library Science, University of North Carolina at Chapel Hill, 1997. 24 pp.

Gleason, Eliza Atkins. The Southern Negro and the Public Library: A Study of the Government and Administration of Public Library Service to Negroes in the South. Chicago: University of Chicago Press, 1941. 218 pp.

Guthrie, Pickett M. "The Impact of Federal Legislation on Public Library Planning in North Carolina, 1956-1965." Master's Paper, School of Library Science, University of North Carolina at Chapel Hill, 1980. 97 pp.

Harton, Jack H., Jr. "Fighting the Good Fight: The American Public Library in World War II." Master's Paper, School of Information and Library Science, University of North Carolina at Chapel Hill, 1989. 96 pp.

Johnson, Elmer D. "Southern Public Libraries in the 1850s: Correcting an Error." Journal of Library History 4 (July 1969): 268-270.

Jones, Plummer Alston, Jr. "From Censorship to Intellectual Freedom to Empowerment: The Evolution of the Social Responsibility of the American Public Library; A Bibliographical Essay." North Carolina Libraries 51 (Fall 1993): 135-37.

Molz, R. Kathleen. "The American Public Library: Its Historic Concern for the Humanities." In Proceedings of a Conference Sponsored by the School of Library 
Science, University of North Carolina at Chapel Hill, 1978, ed. Robert N. Broadus and Brian Nielsen, 30-47. Chicago: American Library Association, 1979.

Morabito, Thomas Gerard. "Book Selection in the Public Library: Historical Precedents and Contemporary Issues." Master's Paper, School of Library Science, 1977. $30 \mathrm{pp}$.

Parker, Lucretia Jeannette. "A Study of Integration in Public Library Service in Thirteen Southern States." Master's Thesis, Atlanta University, 1965. 95 pp.

Ruffin, Cynthia Ann. "The History of Public Library Service to Blacks in North Carolina, 1900-1960." Master's Paper, School of Library Science, University of North Carolina at Chapel Hill, 1983. 89 pp.

Smith, Patricia Christine. "The Tennessee Valley Authority and Its Influence in the Development of Regional Libraries in the South." Master's Paper, School of Library Science, University of North Carolina at Chapel Hill, 1954.

Valentine, Patrick. "The Spread of Public Libraries: The Community of the Book in North Carolina, 1900-1960." North Carolina Libraries 54 (Fall 1996): 113-21.

. "Steel, Cotton, and Tobacco: Philanthropy and the Public Libraries in North Carolina, 1900-1940." Libraries \& Culture 31 (Spring 1996): 272-98.

Von Oesen, Elaine. "Public Library Extension in North Carolina and the WPA." North Carolina Historical Review 29 (July 1952): 379-99.

Wallace, Anne. "The Public Library Movement in the South since 1899." Library Journal 32 (1907): 253-58.

. "The Southern Library Movement in the South since 1899." Bulletin of the American Library Association 1 (June 1907): 62-68.

\section{Alamance County}

Parks, Evelyn. "Post Office to Library: The Evolution of the May Memorial Library Building." North Carolina Libraries 13 (May 1955): 104-7.

\section{Anson County}

Fyan, Loleta D. A Study of the Anson, Stanly \& Union County Public Libraries, North Carolina. s.l.:s.n., 1961. 40 pp.

\section{Ashe County}

Knerr, Valerie Catherine Hiatt. Information for Planning Library Services: A Survey of Ashe, Watauga, and Wilkes Counties. North Wilkesboro: Appalachian Regional Library, 1978. 49 pp.

\section{Beaufort County}

Fletcher, Charlotte. "The Reverend Thomas Bray, Alexander Vattemare, and Library Science." Library Quarterly 27 (Apr. 1957): 95-99.

Gibson, John Kenneth. "The Thomas Bray Libraries, St. Thomas Parish, Pamlico (Bath, North Carolina), 1700: A Bibliographical and Historical Analysis." Master's Paper, School of Library Science, University of North Carolina at Chapel Hill, 1986. 224 pp.

\section{Bertie County}

Byrd, Jessie. "History of the Library." In The Windsor Story, 1768-1968, 129-31. Windsor: Bicentennial Commission, 1960.

\section{Bladen County}

Chung, Jay. Bladen County and Its Library: Community and Library Analysis Report. [Elizabethtown]: Bladen County Library, 1977. 103 pp. 


\section{Brunswick County}

King, Susan. "Southport Public Library and Its Book-of-the-Month Club Award." North Carolina Libraries 22 (Spring 1964): 75-78.

\section{Buncombe County}

"Asheville's New Brand Library [and] Pack Memorial Annex." North Carolina Libraries 12 (Oct. 1953): 2-5.

Chait, William, and Ruth E. Warncke. Survey of the Public Library of Asheville and Buncombe County, North Carolina. Chicago: American Library Association, 1965.

Gillis, Donald. "The New Pack Memorial Library, Asheville." North Carolina Library Bulletin 6 (Sept. 1926): 179-81.

Myrick, James Robert. "The History of the Asheville Public Library." Master's Paper, School of Library Science, University of North Carolina at Chapel Hill, 1977. $114 \mathrm{pp}$.

\section{Burke County}

"New Library Buildings." North Carolina Libraries 12 (Apr. 1954): 73.

\section{Cabarrus County}

"The Concord Public Library." North Carolina Library Bulletin 2 (Dec. and Jan. 19121913): 6-7.

Garrison, Barbara S. "A History of the Concord Public Library of Concord, North Carolina." Master's Paper, School of Library Science, University of North Carolina at Chapel Hill, 1965.

\section{Caldwell County}

Andrew, Columbus. "Libraries." In "The Economic and Social Foundations and Possibilities of Caldwell County, North Carolina," 52. Master's Thesis, Department of Rural-Social Economics, University of North Carolina, 1928.

\section{Carteret County}

"Carteret County Public Library." In The Heritage of Carteret County, North Carolina, ed. Pat Dula Davis, Kathleen Hill Hamilton, Kay Slaughter Hewitt, Charles O. Pitts and Carteret Historical Research Association, 1, 21. Winston-Salem: Carteret Historical Research Association in cooperation with Hunter Pub. Co., 1982.

\section{Caswell County}

Rudd, Nancy M. "Gunn Memorial Public Library." In The Heritage of Caswell County, North Carolina, ed. Jeannine D. Whitlow and Caswell County Historical Association, 27-28. Winston-Salem: Caswell County Historical Association in cooperation with Hunter Pub. Co., 1985.

\section{Catawba County}

"Catawba County Public Library." In The Heritage of Catawba County, North Carolina, ed. Lucille M. Fulbright and Catawba County Genealogical Society, 1, 11-12. Winston-Salem: Published by the Catawba County Genealogical Society in cooperation with Hunter Pub. Co., 1986.

Duchac, Kenneth F., and H. Thomas Walker. Survey of the Public Libraries of Catawba County, North Carolina: The Ebert Ivey Memorial Library of Hickory and Its Ridgeview Branch, the Catawba County Library, Newton. Chicago: American Library Association, 1966.

"Elbert Ivey Memorial Library." In The Heritage of Catawba County, North Carolina, ed. Lucille M. Fulbright and Catawba County Genealogical Society, 1, 10-11. 
Winston-Salem: Published by the Catawba County Genealogical Society in cooperation with Hunter Pub. Co., 1986.

Owen, Hannah. "Smart Start: One Public Library's Experience." North Carolina Libraries 56 (Winter 1998): 148-51.

Chatham County

"Library Service." In Chatham County 1771-1971, ed. Doris G. H. Hadley and Nell Craig Strowd, 74. s.l.:s.n., 1976.

\section{Cherokee County}

Cooke, Addie M. "A History of the Public Library in Murphy, North Carolina." Master's Thesis, School of Library Science, Florida State University, 1962.

"The Nantahala Regional Library." In The Heritage of Cherokee County, North Carolina, ed. Alice D. White, Nell A. White and Cherokee County Historical Museum, 2, 402. Winston-Salem: Published by Cherokee County Historical Museum in cooperation with Hunter Pub. Co., 1987.

\section{Chowan County}

Palmer, Mary B. "The Shepard-Pruden Memorial Library." North Carolina Library Bulletin 4 (Sept. 1920): 99-100.

Scoggin, Rebecca B. "The Development of Public Library Services in Chowan, Tyrrell, and Washington Counties." Master's Paper, School of Library Science, University of North Carolina at Chapel Hill, 1967.

\section{Cleveland County}

Fryer, Hazel H. "The J.S. Mauney Memorial Library." In The Heritage of Cleveland County, ed. James D. Marler and Cleveland County Historical Association, v. Winston-Salem: Published by the Cleveland County Historical Association in cooperation with Hunter Pub. Co., 1982.

\section{Columbus County}

"Whiteville Library." In Columbus County, North Carolina, Recollections and Records, ed. Ann Ward Little and Columbus County Bicentennial Commission., 56-57. Whiteville: Columbus County Commissioners and Columbus County Public Library, 1980.

\section{Craven County}

"Vanceboro-Craven County Public Library." In The Heritage of Craven County, North Carolina, ed. Barbara M. Howard Thorne and Eastern North Carolina Genealogical Society, 52. Winston-Salem: Published by the Eastern North Carolina Genealogical Society in cooperation with Hunter Pub. Co., 1984.

Watson, Alan D. "Newbern Library Company." In A History of New Bern and Craven County, 178-79. New Bern: Tryon Palace Commission, 1987.

. "New Bern Colored Library." In A History of New Bern and Craven County, 603-604. New Bern: Tryon Palace Commission, 1987.

. "New Bern Library Society." In A History of New Bern and Craven County, 351. New Bern: Tryon Palace Commission, 1987.

\section{Cumberland County}

Cumberland County Public Library. Community Needs and Resources; Report on LibraryCommunity Project, 1958-1960. Raleigh: North Carolina State Library, 1960.

Cumberland County Public Library. Inside and Outside: A Look at Cumberland County and the Cumberland County Public Library, Fayetteville, North Carolina. Fayetteville: Cumberland County Public Library, 1977. 100 pp. 
Johnson, Lucille Miller. "Library's Roots Reach Deep in Local History." In Hometown Heritage, ed. Lucile Miller Johnson and Daughters of the American Revolution, Colonel Robert Rowan Chapter, Vol. 2: 149-51. Fayetteville: Colonel Robert Rowan Chapter National Society Daughters of the American Revolution, 1978.

McAdoo, Jennifer English. "A Study of the Cumberland County Public Library System." Master's Paper, School of Library Science, University of North Carolina at Chapel Hill, 1973. 33 pp.

Mott, Jennifer. "When Communities Divide: The Published Opinion Letters of the 1999 Cumberland County Public Library and Information Center (CCPLIC) Controversy and Their Implications for the Nation's Children." Master's Paper, School of Information and Library Science, University of North Carolina at Chapel Hill, 2000. 56 pp.

Oates, John A. "Cumberland County Public Library." In The Story of Fayetteville and the Upper Cape Fear, 523-24. Fayetteville: Fayetteville Woman's Club, 1981.

Shue, Dorothy E. "A New Building for the Cumberland County Public Library." North Carolina Libraries 11 (Oct. 1952): 3-5.

Simpson, Richard L. Cumberland County Library-Community Survey; a Study of Factors Affecting the Use of Library Services in Cumberland County, N.C. Chapel Hill: University of North Carolina, Institute for Research in Social Science, 1960.

Thrasher, Jerry A. "A New Headquarters Public Library for Cumberland County." North Carolina Libraries 44 (Fall 1986): 190-93.

Wright, Deborah. "A History of Cumberland County Public Library, Fayetteville, North Carolina." Master's Paper, School of Library Science, University of North Carolina at Chapel Hill, 1973. 45 pp.

\section{Currituck County}

Stick, David. "Currituck County Library." In The Heritage of Currituck County, North Carolina, ed. Jo Anna Heath Bates, Albemarle Genealogical Society and Currituck County Historical Society, 22-23. Winston-Salem: Albemarle Genealogical Society in cooperation with the Currituck County Historical Society and Hunter Pub. Co., 1985.

\section{Dare County}

Stick, David. "Library." In Dare County: A History, 51. Raleigh: State Dept. of Archives and History, 1970.

\section{Davidson County}

Bates, Nancy F. "A Twenty-Five-Year-Old Dream Becomes Reality." North Carolina Libraries 43 (Fall 1985): 176-77.

Howell, Ray N. "An Open Book." In Our State (Aug. 2001): 26, 28-30. [History of the Davidson County Public Library.]

McCoy, Mrs. O.J. "County Library for Davidson." North Carolina Library Bulletin 7 (June 1928): 64.

\section{Davie County}

Blackwelder, Mrs. Paul B. "A New Library for Davie County." North Carolina Libraries 25 (Spring 1967): 46-48.

Clement, Blanche H. "The New Davie County Public Library." North Carolina Libraries 13 (Mar. 1955): 71-72.

\section{Duplin County}

McGowen, Faison Wells, and Pearl Canady McGowen. "Duplin County Dorothy 
Wightman Library." In Flashes of Duplin's History and Government, 479-80. Kenansville: s.n., 1971.

\section{Durham County}

Allison, Evie L. "Miss Kiwanis." North Carolina Library Bulletin 6 (Mar. 1927): 226-28.

Anderson, Jean Bradley. Durham County: A History of Durham County. Durham: Duke University Press, 1990. 611 pp.

Bomar, Cora P., and C. Jenkins. "Durham County, N.C.: First Place." Wilson Library Bulletin 29 (Jan. 1965): 397-98.

Brooks, Mrs. B.W. "The Durham Public Library." North Carolina Library Bulletin 3 (Sept. 1916): 31-32.

Crawford, Clara M. "County Service in Durham, North Carolina." North Carolina Library Bulletin 5 (June 1924): 204-5.

Dickey, Ellen Elizabeth. "Survey of the African American Population in Durham County, North Carolina: A History of the Bragtown Branch Library." Master's Thesis, North Carolina Central University, 1993. 42 pp.

Flythe, Frances H. "Identification of the Information Needs of Newly Arrived Hispanic / Latino Immigrants in Durham County, North Carolina, and How the Public Library May Address Those Needs." Master's Paper, School of Information and Library Science, University of North Carolina at Chapel Hill, 2001. 57 pp.

Givens, Merilyn. "A Comparison of Collection Development Philosophies of Two North Carolina Libraries: The Effects on Quality and Use." Master's Paper, School of Information and Library Science, University of North Carolina at Chapel Hill, 1991. 33 pp.

Griggs, Mrs. A.F. "The Durham Public Library.” North Carolina Library Bulletin 4 (Sept. 1921): 164.

Harland-Jacobs, Jessica. The History of Public Library Service in Durham, North Carolina, 1897 to 1997. Durham: Durham County Public Library, 1998. 56 pp.

High, Walter Mountain III. "A History of the Durham Public Library, 1895-1940." Master's Paper, School of Library Science, University of North Carolina at Chapel Hill, 1976. 71 pp.

“A History of the Durham Public Library, 1895-1940." North Carolina Libraries 34 (Winter 1977): 35-48.

Jones, Beverly W. Stanford L. Washington Branch Library, 77 Years of Public Service: A Phoenix in the Durham Community. Durham: Durham County Library, 1990. 134 pp.

Lohr, Susan J. "Publicity and Summer Reading Clubs in Public Libraries: A Case Study." Master's Paper, School of Information and Library Science, University of North Carolina at Chapel Hill, 1989. 68 pp.

McCoy, Earnestine C. "A Historical Study of Stanford L. Warren Branch of the Durham Public Library (1955 through 1990)." Master's Thesis, North Carolina Central University, 1994. 134 pp.

Pipkin, Michael. "A Survey of the Holders of Expired Borrower's Cards in the Libraries of Durham, N.C." Master's Paper, School of Library Science, University of North Carolina at Chapel Hill, 1963.

Webb, Mena. "Durham County Library's Founding Spawned Varying Tales." In The Way We Were: Remembering Durham, 46-52. Durham: Historic Preservation Society of Durham, 2003. 
Weber, Terry Lynn. "A User Survey of the Durham County Library." Master's Paper, School of Library Science, University of North Carolina at Chapel Hill, 1984. $58 \mathrm{pp}$.

\section{Edgecombe County}

"Edgecombe County Memorial Library." In Echoes of Edgecombe County, 1860-1940, ed. Monika S. Fleming, 2, 120. Dover, N.H.: Arcadia Pub., 1996.

Watson, Helen R. “The Books They Left: Some 'Liberies' in Edgecombe County, 17531783." North Carolina Historical Review 48 (July 1971): 245-47.

\section{Forsyth County}

Ballance, Paul S. "The East Winston Branch Library." North Carolina Libraries 13 (May 1955): 96-98.

. The First Fifty Years of Public Library Service in Winston-Salem, 1906-1956.

Winston-Salem: s.n., 1956. 44 pp.

"Winston-Salem's New Public Library." North Carolina Libraries 12 (Oct. 1953): 18-20.

and Jeannette Trotter. "Winston-Salem Public Library." North Carolina Libraries 10 (Apr. 1952): 36-37.

Govern, Jim. "The Clemmons Branch Library." North Carolina Libraries 42 (Winter 1984): 195-97.

Moore, Bonnie L. "A History of Public Library Service to Negroes in Winston-Salem, North Carolina, 1927-1951." Master's Thesis, School of Library Science, Atlanta University, 1961.

Prather, Mary C. "Carnegie Public Library of Winston." North Carolina Library Bulletin 1 (Mar. 1911): 70-72.

Public Library Service for Winston-Salem and Forsyth County, North Carolina: A Plan for City and County Branch Libraries. Winston-Salem: City-County Planning Board, 1963. $47 \mathrm{pp}$.

\section{Franklin County}

Yarborough, Elsa. "Franklin County Library." In Special 100th Anniversary Issue, the Franklin Times: Louisburg, N.C., Thursday, July 30, 1970, ed. Elizabeth Johnson, 41. s.l.:s.n., 1980.

\section{Gaston County}

Gaston-Lincoln Regional Library Today and Tomorrow: A Self-Study, 1977. Gastonia: Gaston-Lincoln Regional Library, 1977. 202 pp.

Garland, Elizabeth Matthews. "The Library in the Political Process: A Case Study." Master's Paper, School of Library Science, University of North Carolina at Chapel Hill, 1976. 28 pp.

Miller, Mrs. J.Y. "The Gastonia Public Library." North Carolina Library Bulletin 3 (June 1918): 119-20.

"The Gastonia Public Library." North Carolina Library Bulletin 8 (June 1931): 48.

\section{Graham County}

Benson, Dorothea. "Graham County Public Library." In Graham County Heritage, North Carolina, ed. Graham County Historical Society, 14. Robbinsville: Graham County Historical Society, 1992.

Ingram, Marion. "The Original Graham County Library." In Graham County Heritage, North Carolina, ed. Graham County Historical Society, 11. Robbinsville:

Graham County Historical Society, 1992. 
Snyder, Phillis M. "Bemis Memorial Library, Robbinsville." North Carolina Libraries 11 (May 1953): 62-65.

\section{Granville County}

"Granville County's New Library." North Carolina Libraries 23 (Winter 1965): 46-47.

Richard H. Thornton Library: A Public Library Sponsored by the Citizens of Granville County. Oxford, N.C.: Richard H. Thornton Library, 1975. 66 pp.

Stevenson, Cheryl Lee. "A History of the Richard H. Thornton Library: First Tax-Supported County Library in the Southeastern United States." Master's Paper, School of Library Science, University of North Carolina at Chapel Hill, 1971. 69 pp.

Thornton, Richard H. "A Dream Come True." North Carolina Libraries 23 (Winter 1965): 47-48.

\section{Guilford County}

Burwell, Olivia B. "A Picture Tour through the Greensboro Public Library." North Carolina Libraries 23 (Summer 1965): 100-4.

Caldwell, Bettie D. "Greensboro Public Library, Carnegie Building." Library Journal 31 (1906): 718-19.

Caldwell, Bettie D. "The Greensboro Public Library." North Carolina Library Bulletin 1 (Sept.-Dec. 1910): 35-38.

Carlson, Anne Page. "Cooperation among the Public Libraries of the Piedmont Triad, Region G, North Carolina." Master's Paper, School of Library Science, University of North Carolina at Chapel Hill, 1977. 46 pp.

Carmichel, James V., Jr. "Librarian with a Love for Young Readers." Tar Heel Junior Historian 33, (Spring 1994): 30. [Profile of Greensboro Public Library librarian Nellie Rowe.]

Doms, Keith, and Henry G. Shearouse, Jr. Library Service for Greensboro and Guilford County, North Carolina. Chicago: American Library Association, 1960. 35 pp.

Hays, Timothy Paul, and Concepcion Shimuzu Wilson. A Survey of Users and Nonusers of Public Libraries in Region $G$, North Carolina. Greensboro: Piedmont Triad Council of Governments, 1974. 109 pp.

"High Point Public Library." http://www.hipopl.org/Home/history/. Accessed Mar. 2004.

Lamb, Daryle Lawson. "Alonzo Hall Towers: A Greensboro Public Library Experiment in Library Service to the Elderly." Master's Paper, School of Library Science, University of North Carolina at Chapel Hill, 1977. 49 pp.

Lee, E. Frank. "The Greensboro Public Library." North Carolina Library Bulletin 3 (Dec.-Mar. 1916-1917): 52-53.

"Library Extension in Guilford." North Carolina Library Bulletin 2 (Mar. 1915): 97-98.

Rowe, Nellie M. "Autograph Collection at Greensboro Public Library." North Carolina Library Bulletin 6 (June 1925): 51-52.

. "The Guilford County Book-Truck." North Carolina Library Bulletin 6 (June 1927): 242-43.

Snow, Helen. The Greensboro Public Library: The First 100 Years. Virginia Beach, Va.: Donning Co. Publishers, 2003. 79 pp.

Stewart, William L., Jr. "A History of the High Point, North Carolina, Public Library." Master's Paper, School of Library Science, University of North Carolina at Chapel Hill, 1963.

Viele, George B., and Shirley L. Windham, eds. Greensboro Public Library: A Study of the Library and Its Community; or, the Apex of Library Service. Greensboro: Greensboro Public Library, 1977. 71 pp. 